Praca poglądowa/Review

\title{
Zajęcie ośrodkowego układu nerwowego w przebiegu szpiczaka plazmocytowego - opis przypadku i przegląd literatury
}

\section{Central nervous system involvement in multiple myeloma - case report and review of the literature}

\author{
Artur Jurczyszyn ${ }^{1, *}$, Magdalena Olszewska-Szopa ${ }^{2}$, Szymon Fornagiel ${ }^{3}$, \\ Aleksander Skotnicki ${ }^{1}$ \\ ${ }^{1}$ Katedra i Klinika Hematologii Collegium Medicum UJ w Krakowie, Polska \\ ${ }^{2}$ Poradnia Hematologiczna oraz Oddział Dzienny Onkologii Uniwersyteckiego Szpitala Klinicznego we Wrocławiu, \\ Polska \\ ${ }^{3}$ Oddział Kliniczny Hematologii Szpitala Uniwersyteckiego w Krakowie, Polska
}

IN F ORMACJE O ARTYKULE

Historia artykułu:

Otrzymano: 07.04.2015

Zaakceptowano: 20.04.2015

Dostępne online: 23.04.2015

Słowa kluczowe:

- szpiczak

- ośrodkowy układ nerwowy

- diagnostyka

- leczenie

Słowa kluczowe:

- Myeloma

- Central nervous system

- Diagnosis

- Treatment

\section{A B S T R A C T}

In multiple myeloma extramedullary involvement occurs in $13 \%$ of patients. Central nervous system (CNS) involvement is extremely rare and comprises $1 \%$ of cases. Review of literature shows only limited data on this subject and consists mostly of few case reports. Scarce knowledge about CNS involvement in the course of multiple myeloma makes its diagnosis and treatment very difficult and challenging. The authors describe a clinical case which illustrates the problem from a clinician point of view. Furthermore, we analyzed the available data from literature and summarized the current state of knowledge on diagnosis, potential prognostic factors, treatment and prognosis in CNS myeloma involvement.

(C) 2015 Polskie Towarzystwo Hematologów i Transfuzjologów, Instytut Hematologii i Transfuzjologii. Published by Elsevier Sp. z o.o. All rights reserved.

* Adres do korespondencji: Klinika Hematologii, Szpital Uniwersytecki, ul. Kopernika 17, 31-501 Kraków, Polska. Tel.: +48 601539077.

Adres email: mmjurczy@cyf-kr.edu.pl (A. Jurczyszyn).

http://dx.doi.org/10.1016/j.achaem.2015.04.005

0001-5814/@ 2015 Polskie Towarzystwo Hematologów i Transfuzjologów, Instytut Hematologii i Transfuzjologii. Published by Elsevier Sp. $\mathrm{z}$ o.o. All rights reserved. 


\section{Wstęp}

W ostatnich latach coraz więcej uwagi poświęca się pozaszpikowym lokalizacjom szpiczaka plazmocytowego. Zmiany pozaszpikowe pojawiają się u około 7\% chorych przy rozpoznaniu, a u kolejnych $6 \% \mathrm{w}$ toku choroby [1]. $\mathrm{Z}$ nieznanych przyczyn lokalizacja w ośrodkowym układzie nerwowym jest bardzo rzadka - szacuje się, że stanowi niespełna 1\% przypadków [2]. Odmiennie sytuacja wygląda w odniesieniu do chłoniaków nieziarniczych, gdzie wtórne zajęcie ośrodkowego układu nerwowego (OUN) stwierdza się kilka do kilkunastu razy częściej. Dotychczas opublikowano niewiele opisów przypadków zajęcia OUN, brakuje w literaturze usystematyzowanych informacji na temat diagnostyki i leczenia w takich sytuacjach.

\section{Opis przypadku}

W kwietniu 2011 roku 63-letnia pacjentka zgłosiła się do szpitalnego oddziału ratunkowego $\mathrm{z}$ powodu silnego bólu w okolicy lędźwiowo-krzyżowej z towarzyszącymi osłabieniem, nudnościami i wymiotami. Ponadto chora podawała w wywiadzie przewlekłą obturacyjną chorobę płuc. W badaniu RTG kręgosłupa zobrazowano złamanie kompresyjne kręgu L1 i zmiany zwyrodnieniowe kręgosłupa w odcinku L-S. W wykonanej wówczas morfologii krwi obwodowej stwierdzono niedokrwistość - Hb 6,33 mmol/l $(10,2 \mathrm{~g} / \mathrm{dl})$. Po normalizacji wyników chorą wypisano do domu bez zaleceń dalszego postępowania, dopiero po sześciu miesiącach pacjentka trafiła do hematologa w ramach diagnostyki anemii. Niedokrwistość pogłębiła się do tego czasu i wynosiła 5,34 mmol/l (8,6 g/dl). W rozmazie ręcznym krwi obwodowej stwierdzono wówczas pojedyncze plazmocyty. Poza tym badania laboratoryjne wykazały wysokie OB $125 \mathrm{~mm} / \mathrm{h}$, podwyższone stężenie białka całkowitego $131 \mathrm{~g} / \mathrm{l}$ oraz obecność białka monoklonalnego 67 g/l. Przeprowadzono trepanobiopsję, stwierdzając 75\% naciek klonalnych atypowych plazmocytów CD138+/к+. Rozpoznano szpiczaka IgG $\lambda$ IIIA w klasyfikacji Duriego i Salmona. Rozpoczęto chemioterapię w schemacie CD (cyklofosfamid + deksametazon).

Po dwóch kursach chemioterapii CD stan chorej uległ pogorszeniu w związku z wystąpieniem zaostrzenia POChP i wtórną niewydolnością lewokomorową serca. Pacjentka została przyjęta do szpitala, włączono antybiotykoterapię. W czwartej dobie hospitalizacji doszło u chorej do zaburzeń świadomości. Przedmiotowo stwierdzono bradykardię $35 / \mathrm{min}$, dodatnie objawy oponowe i gorączkę do $39^{\circ} \mathrm{C}$. W badaniu TK OUN nie wykazano odchyleń. Stwierdzono bakteriemię Streptococcus pneumoniae. Wykonano punkcję płynu mózgowo-rdzeniowego (pmr), stwierdzając ten sam patogen co we krwi oraz pleocytozę - głównie granulocytarną. W badaniu RTG klp. zobrazowano liczne plamiste ogniska naciekowe odpowiadające zapaleniu płuc w przebiegu infekcji S. pneumoniae. Po eskalacji antybiotykoterapii (podano Meronem $3 \times 2 \mathrm{~g}$ oraz wankomycynę $2 \times 1 \mathrm{~g}$ ) oraz włączeniu deksametazonu uzyskano niewielką poprawę stanu chorej. Oceniono wówczas odpowiedź na leczenie cytostatyczne - uzyskano ją w stopniu mniejszym niż PR.

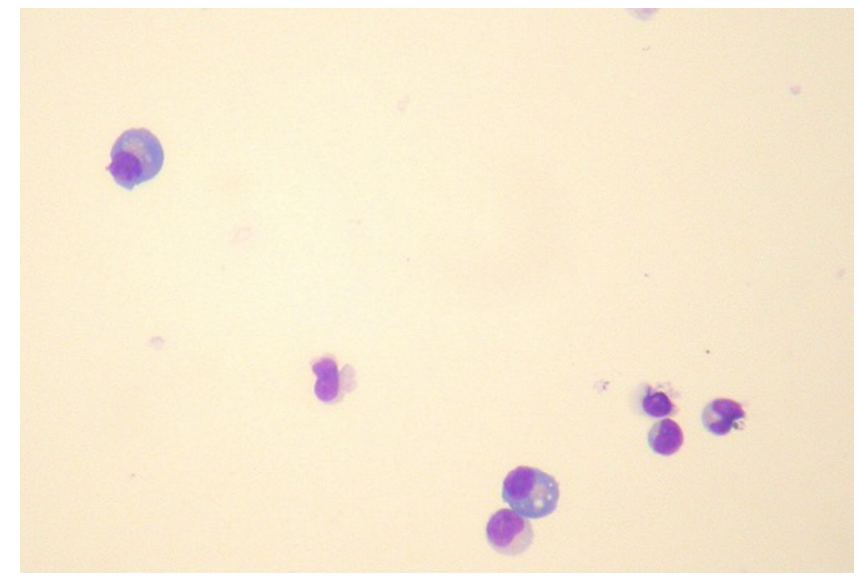

Ryc. 1 - Analiza cytologiczna płynu mózgowo-rdzeniowego. Obecne komórki plazmatyczne. Barwienie metoda Wrighta; powiększenie $\times 1000$

Fig. 1 - Cytological analysis of cerebrospinal fluid - plasma cell infiltration. Wright method coloration; magnification $\times 1000$

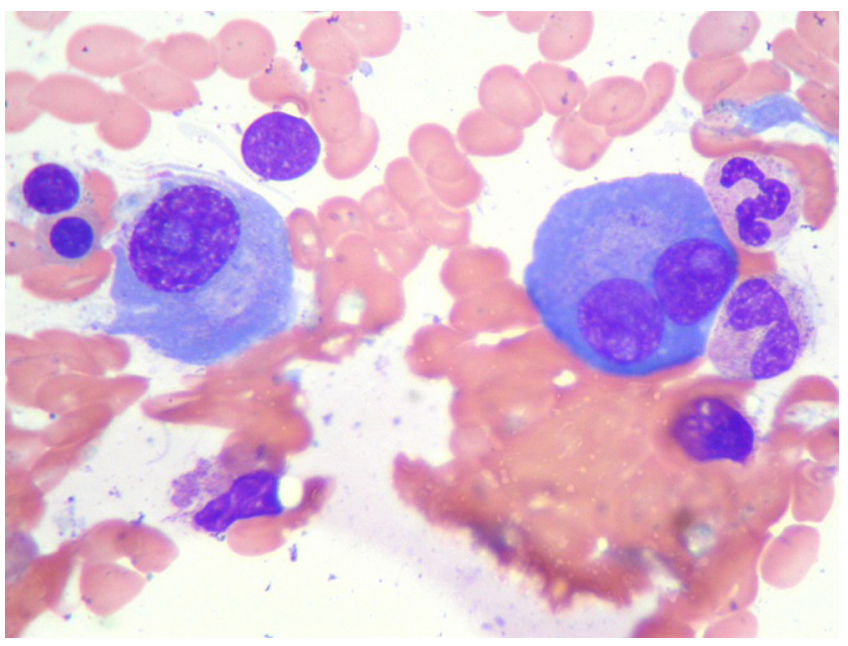

Ryc. 2 - Mielogram - nacieczenie szpiku kostnego przez komórki plazmatyczne. Barwienie metoda Wrighta; powiększenie $\times 1000$

Fig. 2 - Cytological analysis of the bone marrow - plasma cell infiltration. Wright method coloration; magnification $\times 1000$

W trakcie leczenia infekcji stan chorej ulegał stopniowej poprawie. Zmniejszyła się też komórkowość płynu mózgowo-rdzeniowego, jednak wykazano obecność populacji CD138-/ 38+/56-/19-/20-/45-/к+ (Ryc. 1). W wykonanym wówczas rozmazie krwi stwierdzono również atypowe plazmocyty. W badaniu cytologicznym (Ryc. 2) i immunofenotypowym rozmazu szpiku potwierdzono naciek tej samej populacji komórek co w pmr. Plazmocyty były niedojrzałe, o morfologii przypominającej plazmablasty.

W marcu 2012 r. chora została ponownie przyjęta do Kliniki Hematologii. Jej stan był wówczas zadowalający, zgłaszała umiarkowane dolegliwości bólowe w zakresie kręgosłupa oraz obniżoną tolerancję wysiłku. W wykonanych badaniach obrazowych (RTG, MRI) stwierdzono liczne złamania kompresyjne w obrębie piersiowego odcinka kręgosłupa. 
Podano 6 kursów chemioterapii w schemacie CyBorD (cyklofosfamid, bortezomib, deksametazon) i uzyskano PR. Przeprowadzono paliatywną radioterapię (odstąpiono od interwencji neurochirurgicznej).

W listopadzie 2013 r. stwierdzono nawrót choroby pod postacią wzrostu stężenia białka monoklonalnego do $36 \mathrm{~g} / \mathrm{l}$. Zastosowanie trzech kursów chemioterapii opartej na bendamustynie i deksametazonie pozwoliło uzyskać stabilizację choroby trwającą 8 miesięcy. W lipcu 2014 r. wykazano progresję choroby wyrażającą się wzrostem białka monoklonalnego do $47 \mathrm{~g} / \mathrm{l}$. Wdrożono chemioterapię w schemacie VMBCP, jednak przerwano ją po dwóch kursach z powodu dalszej progresji - IgG 52 g/l. We wrześniu 2014 r. pacjentka została zakwalifikowana do programu lekowego NFZ z lenalidomidem. W chwili pisania artykułu pacjentka pozostawała $\mathrm{w}$ stanie dobrym $\mathrm{z}$ bardzo dobrą odpowiedzią częściową (VGPR).

\section{Omówienie}

Choć piśmiennictwo na temat zajęcia OUN w przebiegu szpiczak jest skąpe, autorzy na podstawie dotychczas opublikowanych artykułów podjęli się podsumowania obecnego stanu wiedzy na ten temat.

\section{Diagnostyka}

Rozpoznanie zajęcia OUN może być trudne, ponieważ jego objawy są niespecyficzne i różnorodne. Należą do nich niedowłady, zaburzenia kontroli mikcji, bóle głowy, zaburzenia mentalne, objawy uszkodzenia nerwów czaszkowych [3]. Objawy neurologiczne mogą być w szpiczaku spowodowane przez hiperkalcemię, mocznicę, paraproteinemię oraz uszkodzenia kostne [4]. Leki przeciwszpiczakowe również mają potencjalnie neurotoksyczne działanie, należą do nich m.in. szeroko stosowane talidomid, bortezomib i lenalidomid [5]. Obecność objawów i odchyleń w badaniu neurologicznym nie budzi więc zwykle podejrzenia zajęcia OUN. Charakter zajęcia ośrodkowego układu nerwowego nie jest homogenny. Nacieki mogą dotyczyć w różnym stopniu opon mózgowo-rdzeniowych lub formować lite zmiany w mózgowiu. Rozpoznanie zajęcia OUN stawia się wówczas, gdy stwierdzi się klonalne plazmocyty w płynie mózgowo-rdzeniowym lub naciek w tkankach potwierdzony badaniem histopatologicznym i immunohistochemicznym. Jednak nie zawsze plazmocyty pojawiają się w płynie mózgowo rdzeniowym, a uzyskanie wycinka do badań histopatologicznych jest często trudne $z$ przyczyn technicznych. W przypadku obecności plazmocytów w płynie mózgowo-rdzeniowym ważne jest, by potwierdzić w badaniu immunofenotypowym ich klonalność. Obecność plazmocytów stwierdza się bowiem w różnych stanach chorobowych: kile, zapaleniu opon mózgowo-rdzeniowych o różnej etiologii, SM, toczniu układowym [6]. Plazmocyty mogą być nieobecne $\mathrm{w}$ pmr [7] lub pojawić się dopiero na etapie zaawansowanych zmian naciekowych [8,9]. Brak plazmocytów w pmr może mieć związek z lokalizacją nacieku w obrębie OUN, np. śródmózgowa lub jako izolowane zmiany opony twardej [10]. Stężenie białka w płynie mózgowo-rdzeniowym jest niższe niż we krwi. Nie ustalono norm, więc badania mogą nie być miarodajne. W zajęciu OUN przez chłoniaki stwierdzono kilkukrotne zwiększenie stosunku łańcuchów $\kappa / \lambda$ $\mathrm{w}$ pmr [3]. Zgodnie $\mathrm{z}$ wiedzą autorów nie prowadzono dotychczas takich badań w szpiczaku. Uwidocznienie zajęcia OUN przez szpiczaka często możliwe jest już w badaniach obrazowych. Stwierdzenie zmian nie daje jednak pewnego rozpoznania, wyniki mogą być zarówno pozytywnie, jak i negatywnie fałszywe [11]. Na przykład zmiany w obrębie opon mogą sugerować krwiaki $[12,13]$. Tomografia komputerowa jest mało czuła w zakresie wykrywania zmian szpiczakowych w OUN. Do ich obrazowania z wyboru stosuje się MRI $\mathrm{z}$ gadolinem [14-16]. U około $10 \%$ chorych z zajęciem OUN jednak badanie to może być ujemne [6].

\section{Etiologia i czynniki ryzyka}

W dotychczas opublikowanych materiałach powtarzają się próby identyfikacji czynników promujących zajęcie OUN. Do najczęściej wymienianych należy zaawansowana choroba, wyrażająca się wysokim stopniem w klasyfikacjach Duriego i Salmona oraz ISS. U większości chorych zajęcie OUN jest tylko jednym $\mathrm{z}$ objawów progresji choroby, zdarza się jednak, że to jedyna lokalizacja nawrotu $[6,9,17,18]$. Białaczka plazmocytowa (PL) wymieniana jest przez kilku autorów [7, 19] jako czynnik ryzyka rozsiewu drogą krwi. Jednakże Nieuwenhuizen wraz z zespołem nie stwierdzili w analizowanej przez siebie grupie dużej częstości PL wśród chorych z zajęciem OUN [6]. Postać plazmablastyczna choroby również może sprzyjać naciekom w OUN [13]. Obecnie za pomocą cytometrii przepływowej można wykryć nawet niewielką liczbę krążących we krwi plazmocytów. Sytuacja ta wiązana jest przez autorów kilku analiz, również tych, którzy nie stwierdzili wyraźnej korelacji białaczki plazmocytowej z zajęciem OUN [6, 19], z większym ryzykiem zajęcia OUN. Częstość nacieków w czaszce sąsiadujących z zajętymi w OUN strukturami sprawia, że bierze się pod uwagę możliwość naciekania struktur OUN przez ciągłość [3, 12, 15]. Ponieważ u części chorych nie stwierdza się krążących plazmocytów ani zajęcia struktur kostnych głowy, niektórzy autorzy wysuwają inne hipotezy dotyczące mechanizmu rozprzestrzeniania się zmian do OUN. Petersen [19] przedstawił tezę o krążących komórkach progenitorowych dla plazmocytów, które miałyby być źródłem przerzutów. W części publikowanych analiz zauważono nadreprezentację rzadkich typów szpiczaka, jak IgA 28-30\% i IgD 3-12\% oraz postaci biklonalnej 3-5\% [6, 16, 19]. Udowodniono już, że niekorzystny profil cytogenetyczny jest związany z gorszym rokowaniem i bardziej agresywnym przebiegiem szpiczaka. W artykułach opisujących przypadki naciekania OUN w szpiczaku podaje się również częstsze występowanie aberracji chromosomalnych. Chang [20] stwierdził, że 8 spośród 9 badanych chorych z zajęciem OUN było homozygotami pod względem del17p, a 4 miało del13q. Fassas [13] u 14 z 25 chorych stwierdził del13q, u 7 zaś zaburzenia $\mathrm{w}$ obrębie chromosomu 11 . W niektórych pracach wiązano wysoki LDH z większym ryzykiem zajęcia OUN [16], ale nie wszyscy autorzy to potwierdzają [6]. Trwają dyskusje nad znaczeniem ekspresji CD56 - molekuły adhezyjnej, na plazmocytach w tworzeniu nacieków w tkankach miękkich. 
Wysunięto hipotezę, że odgrywa to rolę również w ułatwianiu zajmowania OUN [20]. Jednak nie potwierdzono jej w kolejnych analizach [21].

\section{Leczenie}

Dotychczas uzyskane dane $\mathrm{z}$ uwagi na stosunkowo niewielką liczbę chorych i heterogenność analizowanych grup są zbyt skąpe, by wysnuwać wiążące wnioski. Nie znaleziono dotychczas skutecznej metody leczenia. Wydaje się, że systemowa chemioterapia nie wpływa istotnie na nacieki szpiczakowe w OUN ze względu na brak lub słabą penetrację leków przez barierę krew-mózg. Glikokortykosteroidy co prawda penetrują do OUN, ale ich skuteczność w monoterapii jest znikoma, nadają się raczej na składnik terapii wielolekowej. Dodatkowym korzystnym działaniem glikokortykosteroidów jest zmniejszanie toksyczności leków podawanych dokanałowo. Znaleziono pojedyncze doniesienia sugerujące korzystny wpływ chemioterapii systemowej w obrębie OUN. Przykładem może by przypadek opisany przez Mendeza i wsp., w którym uzyskano przejściową poprawę kliniczną i laboratoryjną po 2 kursach VD-PACE [10]. Talidomid przenika do OUN, znany jest na przykład jego efekt sedatywny [7]. Po doustnym zażyciu talidomidu już przy dawce $100 \mathrm{mg} / \mathrm{d}$ można stwierdzić obecność leku w płynie mózgowo-rdzeniowym [22]. Na efekt działania talidomidu trzeba jednak czekać kilka do kilkunastu tygodni, co może tłumaczyć stosunkowo słabą skuteczność leku w sytuacji o zwykle agresywnym i szybkim przebiegu [23]. Wykazano, choć nie w badaniach z udziałem ludzi, że lenalidomid również penetruje do OUN [24]. Z badań na zwierzętach wynika, że pomalidomid penetruje do OUN [15]. W opisanym przez Mussettiego [25] przypadku u pacjenta z pozaszpikowym zajęciem MM (m.in. z zajęciem OUN) uzyskano ustąpienie plazmocytów w pmr po zastosowaniu pomalidomidu. Bortezomib nie penetruje do OUN. Co prawda opublikowano doniesienia, że nacieki nowotworowe glioblastoma zwiększają przepuszczaność bariery krewmózg dla bortezomibu, ale dotychczas nie udokumentowano skuteczności leku w zajęciu OUN u ludzi [15]. Z badań na zwierzętach nie wynika, by karfilzomib penetrował do OUN [24]. Marizomib to, jak dotąd, jedyny spośród inhibitorów proteasomu, który wykazuje aktywność w OUN, w badaniach klinicznych I fazy po jego zastosowaniu stwierdzono m.in. ataksję [24] - jego przydatności klinicznej jeszcze jednak nie udowodniono [7]. Bendamustyna - na podstawie doniesienia o przejściowej poprawie u dwóch spośród trzech chorych z zajęciem OUN przez chłoniaka można przypuszczać, że lek jest potencjalnie przydatny również w zajęciu OUN przez szpiczaka [26]. Topotekan ma udokumentowaną skuteczność w chłoniakach OUN [27]. Uważa się, że uwrażliwia tkanki na działanie radioterapii. Jednak jego aktywność w szpiczaku wydaje się być ograniczona $[16,28]$. Temozolomid, który przekracza barierę krew-mózg, również bywa stosowany w polichemioterapii. Jego skuteczność nie została dobrze udowodniona [16, 28]. Chen i wsp. [7] po analizie 37 przypadków nie zauważyli przewagi bortezomibu, IMIDów czy radioterapii. Jedynie leczenie dokanałowe poprawiło, ich zdaniem, $\mathrm{u}$ analizowanych chorych przebieg choroby. Jak wynika $\mathrm{z}$ dostępnej literatury, w leczeniu dokanałowym stosowano głównie metotreksat i arabinozyd cytozyny z glikokortykosteroidami - leki o udowodnionej skuteczności w chłoniakach $[19,20,29-32]$. W pojedynczych doniesieniach opisano ustąpienie objawów neurologicznych lub nawet normalizację wyników badań laboratoryjnych i obrazowych. Jednak wagę tych wyników zmniejsza m.in. stosowanie terapii dokanałowej w połączeniu z systemową: np. VTD-PACE [30]. Autorzy zgadzają się, że leczenie dokanałowe musi być powtarzane wielokrotnie, by można było uzyskać i utrzymać korzystny efekt [16]. Nie udowodniono, by leczenie dokanałowe wystarczało jako jedyna forma terapii [31]. Wydaje się, że radioterapia całego mózgowia to opcja w rozsianym zajęciu OUN, trzeba się jednak liczyć z dużą toksycznością. W zajęciu lokalnym zaś można stosować radioterapię ograniczoną, jednak jej skuteczność wydaje się mniejsza [16]. Peterson [19] po analizie 53 chorych zauważył korzystny wpływ dla OS przy zastosowaniu radioterapii $\mathrm{w}$ połączeniu z leczeniem dokanałowym. Po analizie 109 chorych Nieuwenhuizen [6] sugerował korzyści wynikające z zastosowania RT dla OS: 3 mies. us 0,81 mies. bez zastosowania RT. Zgodnie z literaturą, dawki stosowane z powodzeniem to $60 \mathrm{~Gy}$ [33] i $40 \mathrm{~Gy}$ [34] - osiągano poprawę kliniczną. Nie stwierdzono wyraźnych korzyści przy zastosowaniu dawek rzędu 25-30 Gy [8, 35]. Znaczenie procedury ASCT w zajęciu OUN również nie zostało jeszcze dobrze poznane. Wysokie dawki melfalanu $\left(200 \mathrm{mg} / \mathrm{m}^{2}\right)$ sprawiają, że lek przenika do OUN. Tym, między innymi, tłumaczy się korzystny wpływ ASCT w zajęciu OUN przez szpiczaka w publikowanych doniesieniach [15]. Pojawiają się pojedyncze głosy dotyczące znaczenia alloSCT w zajęciu OUN przez szpiczaka ponieważ efekt przeszczep przeciw chorobie w szpiczaku jest bardzo ograniczony. Quach i wsp. [36] opisali jeden przypadek powtórnego zastosowania alloSCT od tego samego dawcy przy zajęciu OUN na poziomie rdzenia kręgowego. Fassas i wsp. [2] również podali jeden przykład skuteczności tej procedury. Trwają badania nad nowymi substancjami. Przykładem może być VZV - wirus pęcherzykowatego zapalenia jamy ustnej bydła. Zespół z Mayo Clinic wykazał aktywność jego zatenuowanej i zmodyfikowanej wersji w naciekach OUN MM myszy. Jednak bardzo duża toksyczność oddala szanse wykorzystania substancji w praktyce [37]. Jeszcze wiele specyfików oczekuje na sprawdzenie ich potencjału w leczeniu nacieków szpiczaka w OUN. Nie ma na przykład danych co do zdolności penetracji do OUN tak obiecujących leków, jak daratumumab [38].

Rokowanie: Czas od diagnozy do stwierdzenia nacieku w OUN jest bardzo różny. Zmiany te mogą być nawet pierwszym objawem choroby, ale raczej są wyrazem jej zaawansowania. Na podstawie danych z publikacji zakłada się, że czas przeżycia od chwili stwierdzenia zajęcia OUN w szpiczaku wynosi średnio dwa do sześciu miesięcy $[6,15$, 16]. Znaleziono pojedyncze opisy pacjentów żyjących 2-3 lat po stwierdzeniu zajęcia ośrodkowego układu nerwowego przez szpiczaka [33, 34]. Chen i wsp. [7] są zdania, że $\mathrm{u}$ pacjentów $\mathrm{z}$ wyjściowym zajęciem OUN przeżycie jest dłuższe niż wówczas, gdy dojdzie do tego w toku choroby. Prawdopodobnie wynika to $\mathrm{z}$ ogólnego zaawansowania choroby. 


\section{Podsumowanie}

Zajęcie ośrodkowego układu nerwowego w przebiegu szpiczaka to istotny problem kliniczny, prawdopodobnie nie zawsze rozpoznawany. $\mathrm{Z}$ powodu skąpych danych w literaturze brak jest wytycznych na temat jego diagnostyki oraz leczenia. Istnieje potrzeba publikowania oraz analizowania nowych przypadków zajęcia OUN w szpiczaku, by w przyszłości ułatwić postępowanie z takimi chorymi.

\section{Wkład autorów/Authors' contributions}

Według kolejności.

\section{Konflikt interesu/Conflict of interest}

Nie występuje.

\section{Finansowanie/Financial support}

Nie występuje.

\section{Etyka/Ethics}

Treści przedstawione $\mathrm{w}$ artykule są zgodne $\mathrm{z}$ zasadami Deklaracji Helsińskiej, dyrektywami EU oraz ujednoliconymi wymaganiami dla czasopism biomedycznych.

\section{PIŚ M I E N N I C T W O/REFERENCES}

[1] Varettoni M, Corso A, Pica G, et al. Incidence, presenting features and outcome of extramedullary disease in multiple myeloma: a longitudinal study on 1003 consecutive patients. Ann Oncol 2010;21:325-330.

[2] Fassas AB, Muwalla F, Berryman T, et al. Myeloma of the central nervous system: association with high-risk chromosomal abnormalities, plasmablastic morphology and extramedullary manifestations. Br J Haematol 2002;117:103-108.

[3] Gangatharan S, Carney D, Prince H, et al. Emergence of central nervous system myeloma in the era of novel agents. Hematol Oncol 2012;30:170-174.

[4] Usnarska-Zubkiewicz L, Bilińska M, Koszewicz M. et al. Neuropatie obwodowe w przebiegu szpiczaka mnogiego i innych monoklonalnych paraproteinemii. Acta Haematologica Polonica 2008;39:53-62.

[5] Bilińska M, Usnarska-Zubkiewicz L, Dmoszyńska A. Polineuropatia wywołana talidomidem i bortezomibem u chorych na szpiczaka mnogiego, możliwości leczenia bólu neuropatycznego. Zalecenia Polskiej Grupy Szpiczakowej. Contemp oncol 2008;12:441-446.

[6] Nieuwenhuizen L, Biesma D. Central nervous system myelomatosis: review of the literature. Eur J Haematol 2008;80:1-9.

[7] Chen C, Masih-Khan E, Jiang H, et al. Central nervous system involvement with multiple myeloma: long term survival can be achieved with radiation, intrathecal chemotherapy, and immunomodulatory agents. $\mathrm{Br} \mathrm{J}$ Haematol 2013;162:483-488.

[8] Riley J, Russo J, Shipp A, Alsharif M, Jenrette J. Central nervous system myelomatosis with optic neuropathy and intramedullary spinal cord compression responding to radiation therapy. Jpn J Radiol 2011;29:513-516.

[9] Schluterman K, Fassas A, Van Hemert R, Harik S. Multiple Myeloma Invasion of the Central Nervous System. Arch Neurol 2004;61:1423-1429.

[10] Méndez C, Hwang B, Destian S, et al. Intracranial Multifocal Dural Involvement in Multiple Myeloma: Case Report and Review of the Literature. Clin Lymphoma Myeloma Leuk 2010;10:220-223.

[11] Shpilberg K, Esses S, Fowkes M, et al. Imaging of extraosseous intracranial and intraspinal multiple myeloma, including central nervous system involvement. Clin Imaging 2014. http://dx.doi.org/10.1016/j. clinimag.2014.11.017.

[12] Tsang C, Ho L, Tan T. Intracranial multiple myeloma involving the dura. J Clin Neurosci 2006;13:122-123.

[13] Fassas A, Ward S, Muwalla F, Van Hemert, et al. Myeloma of the central nervous system: strong association with unfavorable chromosomal abnormalities and other highrisk disease features. Leuk Lymphoma 2004;45:291-300.

[14] Jurczyszyn A, Małkowski B, Czepiel J, Skotnicki AB. The importance of imaging techniques in the modern treatment of multiple myeloma. Przegl Lek 2014;71:221-230.

[15] Gozzetti A, Cerase A. Novel agents in CNS myeloma treatment. Cent Nerv Syst Agents Med Chem 2014;14:23-27.

[16] Yellu M, Engel J, Ghose A, Onitilo A. Overview of recent trends in diagnosis and management of leptomeningeal multiple myeloma. Hematol Oncol 2014 Dec 19. http://dx. doi.org/10.1002/hon.2185.

[17] Abdallah A, Atrash S, Shahid Z, et al. Patterns of central nervous system involvement in relapsed and refractory multiple myeloma. Clin Lymphoma Myeloma Leuk 2014;14:211-214.

[18] Dennis M, Chu P. A case of meningeal myeloma presenting as obstructive hydrocephalus-a therapeutic challenge. Leuk Lymphoma 2000;40:219-220.

[19] Petersen S, Wagner A, Gimsing P. Cerebral and meningeal multiple myeloma after autologous stem cell transplantation. A case report and review of the literature. Am J Hematol 1999;62:228-233.

[20] Chang H, Sloan S, Li D, Keith Stewart A. Multiple myeloma involving central nervous system: high frequency of chromosome 17p13.1 (p53) deletions. Br J Haematol 2004;127:280-284.

[21] Marini A1, Carulli G, Lari T, et al. Myelomatous meningitis evaluated by multiparameter flow cytometry: report of a case and review of the literature. J Clin Exp Hematop 2014;54:129-136.

[22] Yutaka H, Mariko Y, Shinichiro O, et al. Thalidomide for the treatment of leptomeningeal multiple myeloma. Eur J Haematol 2006;76:358-359.

[23] Vicari P, Ribas C, Sampaio M, et al. Can thalidomide be effective to treat plasma cell leptomeningeal infiltration? Eur J Haematol 2003;70:198-199.

[24] Lee D, Kalff A, Low M, et al. Central nervous system multiple myeloma-potential roles for intrathecal therapy and measurement of cerebrospinal fluid light chains. $\mathrm{Br} \mathrm{J}$ Haematol 2013;162:371-375.

[25] Mussetti A, Dalto S, Montefusco V. Effective treatment of pomalidomide in central nervous system myelomatosis. Leuk Lymphoma 2013;54:846-864.

[26] Renfrow J, Detroye A, Chan M, et al. Initial experience with bendamustine in patients with recurrent primary central 
nervous system lymphoma: a case report. J Neurooncol 2012;107:659-663.

[27] Hoang-Xuan K, Camilleri-Broët S, Soussain C. Recent advances in primary CNS lymphoma. Curr Opin Oncol 2004;16:601-606.

[28] Annibali O, Nobile C, Greco R, et al. The combination topotecan, temozolomide and dexamethasone associated with radiotherapy as treatment of central nervous system myeloma relapse. Int J Hematol 2009;89:513-516.

[29] Chamberlain MC, Glantz M. Myelomatous meningitis. Cancer 2008;112:1562-1567.

[30] Grisold A, Weber C, Hainfellner J, et al. MRI negative meningeal myeloma with abducens nerve palsies responding to intrathecal chemotherapy. J Neurol Sci 2014;347:359-360.

[31] Marjanović S, Mijusković Z, Stamatović D, et al. Multiple myeloma invasion of the central nervous system. Vojnosanit Pregl 2012;69:209-213.

[32] Velasco R, Petit J, Llatjós R, Juan A, Bruna J. Can leptomeningeal myelomatosis be predicted in patients with IgD multiple myeloma? J Clin Neurosci 2010;17:1071-1072.
[33] Pontikoglou C, Fragos C, Kolyvaki E, et al. Multiple myeloma involving the central nervous system: a report of two cases with unusual manifestations. Leuk Lymphoma 2005;46:737-741.

[34] Haegelen C, Riffaud L, Bernard M, Carsin-Nicol B, Morandi $\mathrm{X}$. Dural plasmacytoma revealing multiple myeloma. Case report. J Neurosurg 2006;104:608-6010.

[35] Seftel MD, Maguire J, Voss N, et al. Intra-cerebral relapse following prolonged remission after autologous stem cell transplantation for multiple myeloma. Leuk Lymphoma 2002;43:2399-2403.

[36] Quach H, Ryan G, Ganju V, Prince HM. Effective treatment of leptomeningeal multiple myeloma with total craniospinal irradiation supported by second allogeneic donor stem cell infusion. Bone Marrow Transplant 2005;35:423-424.

[37] Yarde DN, Naik S, Nace RA, et al. Meningeal myeloma deposits adversely impact the therapeutic index of an oncolytic VSV. Cancer Gene Ther 2013;20:616-621.

[38] Jurczyszyn A, Kosmaczewska A, Skotnicki AB. Daratumumab-breakthrough drug in multiple myeloma therapy. Postepy Hig Med Dosw 2014;68:1352-1360. 